\section{Impact of injury-related deaths on life expectancy in China, 2016}

\author{
O impacto dos óbitos por causas externas na \\ expectativa de vida na China, 2016
}

Impacto de los fallecimientos relacionados con lesiones en la esperanza de vida en China, 2016

\begin{abstract}
This study aimed to illustrate the impact of injury-related deaths on life expectancy in China in 2016 and to identify the high-risk population. Standard life tables were used to calculate life expectancy and cause-eliminated life expectancy by utilizing mortality data from the national mortality surveillance system. In 2016, the life expectancy of Chinese residents was 78.91 years. After eliminating injury-related mortality, the life expectancy of the residents increased by 1.13 years, which was higher in male and rural residents compared with female and urban residents. The life expectancy on the Eastern and Central regions increased slowly compared with the Western region. The greatest influencing factor on life expectancy was road traffic injuries, followed by falls. Falls had a greater impact on life expectancy for children under 5 years old and those aged over 65 years. This study indicates that deaths caused by injury had a noteworthy impact on life expectancy in China. More attention should be paid to road traffic injuries, and effective preventive measures should be taken to reduce deaths related to injury to increase the life expectancy of residents, especially in children under 5 years and adults over 65 years. By reducing the deaths caused by injury, the life expectancy level is likely to further improve.
\end{abstract}

Wonds and Injuries; External Causes; Cause of Death; Life Expectancy
Fangwei Li 1

Shujing Wen 2

Qixin Tang 1

Qianyu Zhou 1

Yibin Hao 3

Changqing Sun 1

\author{
Correspondence \\ C. Sun \\ Department of Social Medicine and Health Management, \\ Zhengzhou University. \\ 100, Science Avenue, Zhengzhou, Henan Province, \\ 450001, China. \\ zzugwsy@163.com \\ ${ }^{1}$ Department of Social Medicine and Health Management, \\ Zhengzhou University, Zhengzhou, China. \\ 2 Petrochemical Hospital of Luoyang, Luoyang, China. \\ 3 Zhengzhou People's Hospital, Zhengzhou, China.
}




\section{Introduction}

In 1996, the Harvard School of Public Health classified all diseases into injury and infectious diseases, maternal and child diseases and nutritional deficiencies, and non-communicable diseases. Such an advancement was recognized and recommended by the World Health Organization (WHO). As part of those three groups, injury is a major public health problem, which has been paid more and more attention by the international community, governments and the public 1 . Injury is divided into accidental injury and intentional injury. Among them, accidental injury mainly includes road traffic injuries (RTIs), poisoning, falls, fire and drowning. Intentional injury mainly includes suicide, homicide and war. According to the WHO, more than 5 million people die due to injury worldwide each year. Injury is one of the top five causes of death among residents in most countries, and it is the first cause of death for children between 1 and 14 years old. High incidence of injury causes economic losses and social burdens more than any infectious diseases or chronic non-communicable diseases 2.

According to the WHO, more than $90 \%$ of injury-related deaths occurred in low- and middleincome countries ${ }^{3}$. As a developing country with the largest population in the world, China has an increasing incidence and death rate of injury. Between 700,000 and 800,000 people die from injury every year, accounting for about $11 \%$ of the total number of deaths 4 . In 2016, injury is the leading cause of death among people under 45 years in China. According to the World Bank's survey, China's injury deaths will rise to 2.5 million in 2030 (3.7 times that of 1990) 5 .

As one of the most used demographic indicators, life expectancy refers to the number of years that a person is expected to survive under the age-specific mortality. Life expectancy is an important indicator reflecting the quality of life and the health level of the population in a country or region, which is restricted by the socioeconomic level, environment and medical conditions 6,7,8. The causeeliminated life table reflects the impact of specific diseases on the health and life expectancy of the population 9 .

Currently, the study of life expectancy in China is concentrated on the provincial level with a focus on chronic diseases like cardiovascular disease 10,11,12,13,14. Few studies have evaluated the impact of injury on life expectancy, and almost none of these have been done at a national level. In addition, there are differences in economy, environment, medical insurance level and lifestyle between different districts and regions in China 15,16. Therefore, based on China's national conditions and injury status, we mainly studied the impact of accidental injury (RTIs, poisoning, falls, fire, drowning) and suicide on the life expectancy of Chinese residents. Through in-depth analysis of the impact of the categories of injury on different genders (male and female), different district type (urban and rural) and different regions (Eastern, Central and Western) in 2016, the high-risk population of injury was screened out, providing reference for the formulation of targeted injury prevention measures in China.

\section{Material and Methods}

\section{Data source}

The data of our study were obtained from the China Death Surveillance Database of 2016, which is compiled by the National Health and Family Planning Commission of the People's Republic of China (http://en.nhc.gov.cn/). The database was collected by Death Surveillance Points System (DSPs), which was established in 1978. In 1990, the Chinese academy of preventive medicine established 145 points in 31 provinces (autonomous regions and municipalities), covering about 10 million population, using the principle of multi-stage stratified cluster random sampling. The number of DSPs has since increased to 605, covering more than 300 million population (about $24 \%$ of the population of China). Previous studies have validated the representativeness and quality of data collection in DSPs 17,18. For more information on DSPs, see Liu 19. 


\section{Registration of Deaths and Injury Causes of Death Coding}

The number of deaths at each disease surveillance site is registered. If people died in medical institutions, the doctors would make a diagnosis and fill in the Death Certificate. If people died at home or in other places, the local village doctors (community doctors) would report the death information to township hospitals (community health service centers). According to the medical history or medical diagnosis, which is provided by the deceased's family or other insiders, the doctors in the township hospitals (community health service centers) would diagnose the cause of death and fill in the Death Certificate.

Causes of death are coded based on the 10th edition of the International Classification of Diseases (ICD-10). Major causes of death include injury (ICD-10 codes V01-Y89), road traffic injuries (RTIs) (V06, V01-V04, V99, V89, V87, and V09-V80), poisoning (X40-X49), falls (W00-W19), fire (X00-X09), drowning (W65-W74), and suicide (X60-X84).

\section{Statistical analysis}

In the 1960s, Chiang used stochastic processes to study the impact of diseases on life expectancy, creating the theory of "competitive risk". The basic assumption was that the effects of various causes of death on people are both independent and superimposed 20. He developed the model, indicating the formulas, functions and assumptions. However, his formulas were difficult to understand, so later scholars simplified it. In this study, we used the current life table. Current life table data are obtained from cross-sectional observation. Taking the mortality rates of all age groups in a given year (or period) as known data, and then assuming that the generation born at the same time will die sequentially according to the mortality rates of these age groups until the death of the last one. Then the "probability of dying", "number of deaths", "number of survivors", "life expectancy" and other indicators of this generation in different age groups were calculated, allowing for the creation of a current life table. According to the such table, the cause-eliminated life table can be compiled. This leads to the following three advantages: (1) the life expectancy and the number of survivors of a certain cause of death reasonably explain the degree which the cause of death affected the life of the population; (2) the indicators of the cause-eliminated life table can not only comprehensively explain the effect of a cause of death on the whole population, but also explain the effect of a cause of death on the population of each age group, respectively; (3) the indicators of the cause-eliminated life table are also not affected by the age composition of the population, and are easy to compare with each other 21 .

In order to calculate the life expectancy of residents after eliminating injury-related deaths, we extracted data related to injury from the total deaths and obtained the life expectancy through the standard life table 21. Let $\mathrm{e}_{0}$ and $\mathrm{e}_{0} \mathrm{i}$ represent the life expectancy at birth $(\mathrm{age}=0)$ from the life table and cause-eliminated life table, respectively. Then the increase in life expectancy after removal of the cause of injury is defined as $\Delta_{0} \mathrm{i}=\mathrm{e}_{0} \mathrm{i}-\mathrm{e}_{0}$. At the same time, according to the classification of different ages, genders and districts, we calculated the life expectancy of residents and the impact of different categories of injury on their life expectancy. District type (urban and rural districts) and regions (Eastern, Central and Western China) were classified in line with the standards used by the National Bureau of Statistics of the People's Republic of China.

All data analysis was performed by Excel 2016 (https://products.office.com/) and SPSS software version 22.0 (https://www.ibm.com/).

\section{Results}

\section{Life expectancy of the Chinese population}

In 2016, the life expectancy of Chinese residents was 78.91 years (76.33 years for men, 81.76 years for women). At the same time, estimated life expectancy for urban and rural residents were 79.44 years and 78.63 years, respectively. Life expectancy in the Eastern region was 79.74 years, which was higher than that in the Central (78.72 years) and Western (77.84 years) regions. 


\section{Increases in life expectancy after eliminating injury-related deaths}

The life expectancy of Chinese residents was 80.04 years after eliminating injury-related deaths. The increases in life expectancy was estimated at 1.13 years, showing that injury was the third leading cause (paralleled with respiratory diseases) of death after cardiovascular diseases (8.71 years) and cancer (2.91 years) (Figure 1).

When classified by gender, after eliminating injury-related deaths, the life expectancy for men and women was 77.75 and 82.54 years, respectively; in addition, the increases in life expectancy for men and women was 1.42 and 0.78 years, respectively. These figures were 80.29 years for urban residents and 79.90 for rural residents, with the increases of 0.85 and 1.27 years, respectively. When classified by region, the life expectancy of residents in the Eastern, Central and Western regions after removing injury-related deaths were $80.74,79.82$, and 79.21 years, representing increases of $1.00,1.10$, and 1.37 years, respectively.

In addition, our comparison of different age groups indicated that the increases in life expectancy after removing injury-related deaths diminished gradually as age increased. Compared with 2006, the increases in life expectancy after removing injury-related deaths in 2016 was smaller. The impact of categories of injury on different age groups in 2006 (Table 1; Figure 2).

\section{Effects of different categories of injury on life expectancy}

Among the categories of injury analyzed, our study showed that the increases in life expectancy were highest after removing RTIs, followed by falls (0.19 years), suicide (0.14 years) and drowning (0.12 years). After removing RTIs, the increases in life expectancy for Chinese residents was 0.39 years. When stratified by gender, district type and region, these figures were 0.54 for men, 0.22 for women, 0.29 for urban residents, 0.45 for rural residents, and 0.36, 0.40 and 0.45 years for residents in the Eastern, Central, and Western regions, respectively. Compared with 2006, life expectancy loss caused by RTIs was higher in 2016. In addition, the life expectancy loss due to suicide in 2016 was less than in 2006. The impact of categories of injury on different gender, district type and regions in 2006 (Table 2; Table 3).

Furthermore, after eliminating mortality resulting from other categories of injury, including falls, suicide, drowning, poisoning and fire, we found that male life expectancy increased more than female, and life expectancy of the rural residents increased more than that of their urban counterparts. In

Figure 1

Life expectancy of Chinese residents after eliminating the leading causes of deaths, 2016.

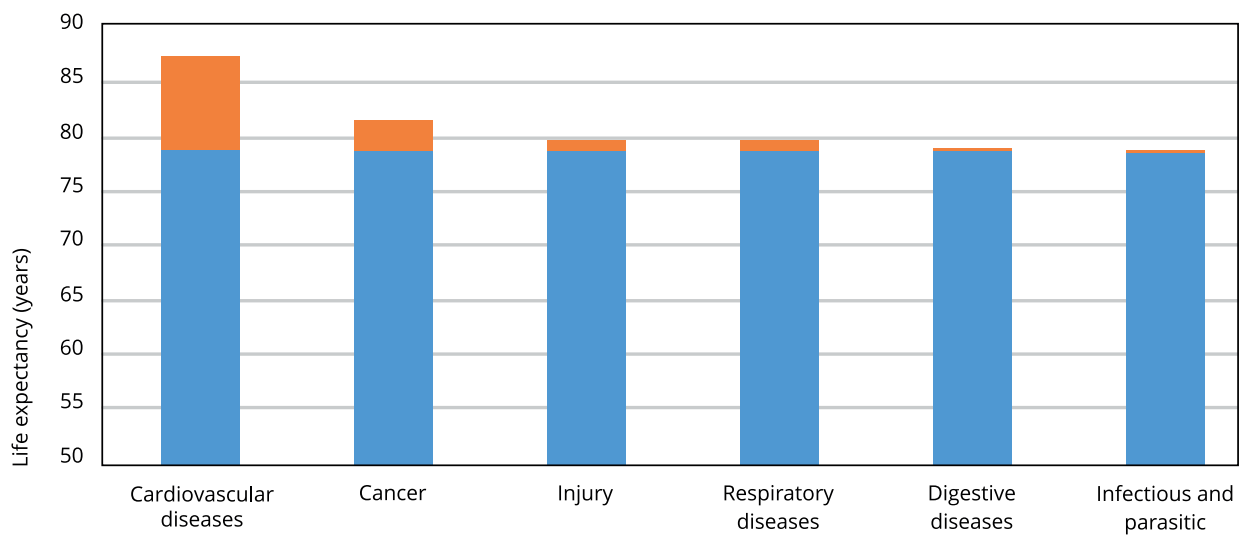

Life expectancy

Life expectancy increase 
addition, eliminating death from these causes had a greater effect on the Western region when compared with the Central and Eastern regions. However, the increases in life expectancy in the Central region was higher than in the Eastern and Western regions after eliminating suicide.

For residents over the age of 65 , eliminating deaths attributed to falls had a conspicuous impact on the increases in life expectancy. At the same time, we observed that eliminating deaths due to falls had a greater impact than eliminating mortality due to drowning among children under 5 years of age (Table 1).

\section{Discussion}

The main findings of our study suggested that injury was the third leading cause of death affecting Chinese life expectancy, after removing the effects of cardiovascular disease and cancer on life expectancy in 2016. Compared with 2006, the life expectancy of residents increased less after removing injury-related deaths, and life expectancy loss caused by RTIs increased in 2016; however, life expectancy loss caused by suicide decreased. In 2016, the loss of life expectancy due to injury was higher for male and rural populations than for female and urban populations. Similarly, the Western residents had a greater loss of life expectancy caused by injury than the Eastern and Central residents. Among the categories of injury, RTIs were the leading cause of loss of life expectancy for residents, while falls were the main cause of premature death for those under 5 years old and adults aged over 65 years. Our findings suggested that the injury is a major public health problem in China.

Table 1

Increases in life expectancy for different age groups after eliminating injury-related deaths. China, 2016.

\begin{tabular}{|c|c|c|c|c|c|c|c|c|c|}
\hline \multirow[t]{2}{*}{ Age (years) } & \multirow{2}{*}{$\begin{array}{c}\text { Life } \\
\text { expectancy } \\
\text { (years) }\end{array}$} & \multirow{2}{*}{$\begin{array}{l}\text { Injury-eliminated } \\
\text { life expectancy } \\
\text { (years) }\end{array}$} & \multicolumn{7}{|c|}{ Increase in life expectancy (years) } \\
\hline & & & Injury & RTI & Poisoning & Fall & Fire & Drowning & Suicide \\
\hline 0 & 78.91 & 80.04 & 1.13 & 0.39 & 0.07 & 0.19 & 0.01 & 0.12 & 0.14 \\
\hline $1-5$ & 78.20 & 79.32 & 1.12 & 0.39 & 0.07 & 0.19 & 0.01 & 0.12 & 0.14 \\
\hline $5-10$ & 74.33 & 75.39 & 1.06 & 0.38 & 0.06 & 0.19 & 0.01 & 0.10 & 0.14 \\
\hline $10-15$ & 69.40 & 70.42 & 1.02 & 0.37 & 0.06 & 0.18 & 0.01 & 0.08 & 0.14 \\
\hline $15-20$ & 64.48 & 65.46 & 0.98 & 0.36 & 0.06 & 0.18 & 0.01 & 0.07 & 0.14 \\
\hline $20-25$ & 59.58 & 60.50 & 0.92 & 0.33 & 0.06 & 0.18 & 0.01 & 0.05 & 0.13 \\
\hline $25-30$ & 54.66 & 55.54 & 0.88 & 0.31 & 0.05 & 0.17 & 0.01 & 0.05 & 0.13 \\
\hline $30-35$ & 49.81 & 50.62 & 0.81 & 0.28 & 0.05 & 0.17 & 0.01 & 0.05 & 0.12 \\
\hline $35-40$ & 45.00 & 45.73 & 0.73 & 0.25 & 0.05 & 0.17 & 0.01 & 0.04 & 0.11 \\
\hline $40-45$ & 40.19 & 40.86 & 0.67 & 0.22 & 0.05 & 0.16 & 0.01 & 0.04 & 0.10 \\
\hline $45-50$ & 35.47 & 36.08 & 0.61 & 0.19 & 0.04 & 0.15 & 0.01 & 0.04 & 0.10 \\
\hline $50-55$ & 30.84 & 31.38 & 0.54 & 0.16 & 0.03 & 0.14 & 0.01 & 0.03 & 0.08 \\
\hline $55-60$ & 26.59 & 27.03 & 0.44 & 0.12 & 0.02 & 0.13 & 0.00 & 0.02 & 0.07 \\
\hline $60-65$ & 22.18 & 22.58 & 0.40 & 0.10 & 0.02 & 0.13 & 0.01 & 0.02 & 0.06 \\
\hline $65-70$ & 18.25 & 18.59 & 0.34 & 0.07 & 0.02 & 0.12 & 0.01 & 0.02 & 0.05 \\
\hline $70-75$ & 14.61 & 14.90 & 0.29 & 0.05 & 0.02 & 0.12 & 0.01 & 0.02 & 0.04 \\
\hline $75-80$ & 11.24 & 11.49 & 0.25 & 0.03 & 0.01 & 0.12 & 0.01 & 0.02 & 0.03 \\
\hline $80-85$ & 8.20 & 8.42 & 0.22 & 0.02 & 0.01 & 0.12 & 0.01 & 0.01 & 0.02 \\
\hline $\begin{array}{l}85 \text { and } \\
\text { more }\end{array}$ & 5.82 & 6.04 & 0.22 & 0.02 & 0.01 & 0.13 & 0.01 & 0.01 & 0.02 \\
\hline
\end{tabular}

RTI: road traffic injury.

Source: China Death Surveillance Database, 2016 (http://en.nhc.gov.cn/). 
Figure 2

Increases in life expectancy by age group after eliminating different categories of injury. China, 2016.

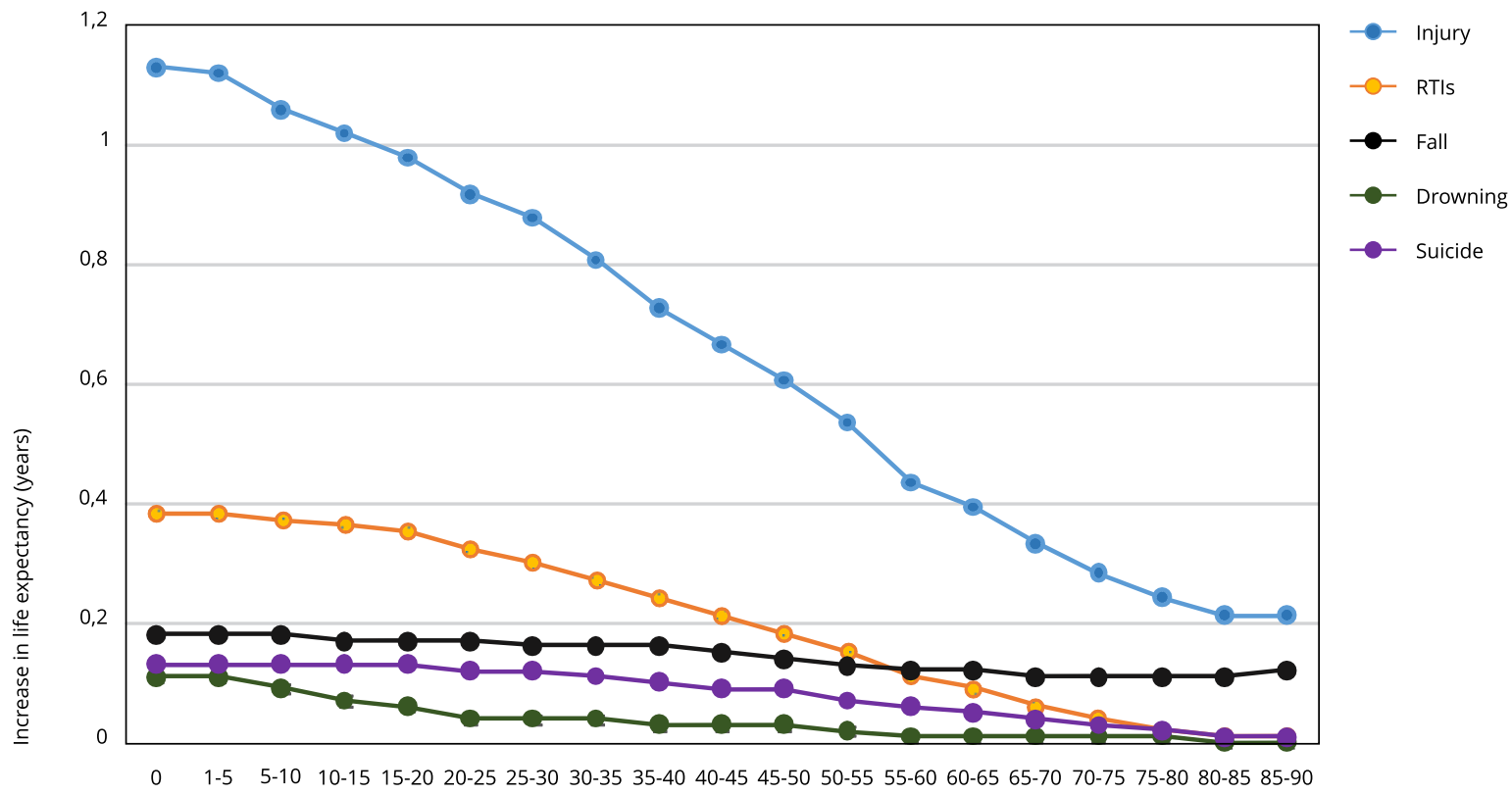

Age groups (years)

RTI: road traffic injury.

\section{Table 2}

Increases in life expectancy by gender and district type of residence after eliminating injury-related deaths. China, 2016.

\begin{tabular}{|c|c|c|c|c|c|c|c|c|c|c|}
\hline \multirow[t]{2}{*}{ Rank } & \multicolumn{2}{|c|}{ All } & \multicolumn{2}{|c|}{ Men } & \multicolumn{2}{|c|}{ Women } & \multicolumn{2}{|c|}{ Urban areas } & \multicolumn{2}{|c|}{ Rural areas } \\
\hline & Injury type & $\begin{array}{c}\text { Increase } \\
\text { in life } \\
\text { expectancy }\end{array}$ & Injury type & $\begin{array}{c}\text { Increase } \\
\text { in life } \\
\text { expectancy }\end{array}$ & Injury type & $\begin{array}{l}\text { Increase } \\
\text { in life } \\
\text { expectancy }\end{array}$ & Injury type & $\begin{array}{l}\text { Increase } \\
\text { in life } \\
\text { expectancy }\end{array}$ & Injury type & $\begin{array}{c}\text { Increase } \\
\text { in life } \\
\text { expectancy }\end{array}$ \\
\hline 1 & RTI & 0.39 & RTI & 0.54 & RTI & 0.22 & RTI & 0.29 & RTI & 0.45 \\
\hline 2 & Fall & 0.19 & Fall & 0.22 & Fall & 0.17 & Fall & 0.17 & Fall & 0.20 \\
\hline 3 & Suicide & 0.14 & Drowning & 0.17 & Suicide & 0.13 & Suicide & 0.10 & Suicide & 0.16 \\
\hline 4 & Drowning & 0.12 & Suicide & 0.16 & Drowning & 0.08 & Drowning & 0.08 & Drowning & 0.14 \\
\hline 5 & Poisoning & 0.07 & Poisoning & 0.09 & Poisoning & 0.05 & Poisoning & 0.05 & Poisoning & 0.08 \\
\hline 6 & Fire & 0.01 & Fire & 0.02 & Fire & 0.01 & Fire & 0.01 & Fire & 0.01 \\
\hline
\end{tabular}

RTI: road traffic injury.

Source: China Death Surveillance Database, 2016 (http://en.nhc.gov.cn/). 
Table 3

Increases in life expectancy by region of residence after eliminating injury-related deaths. China, 2016.

\begin{tabular}{|c|c|c|c|c|c|}
\hline \multicolumn{2}{|c|}{ Eastern region } & \multicolumn{2}{|c|}{ Central Region } & \multicolumn{2}{|c|}{ Western region } \\
\hline Injury type & $\begin{array}{c}\text { Increase in life } \\
\text { expectancy }\end{array}$ & Injury type & $\begin{array}{c}\text { Increase in life } \\
\text { expectancy }\end{array}$ & Injury type & $\begin{array}{c}\text { Increase in life } \\
\text { expectancy }\end{array}$ \\
\hline $\mathrm{RTI}$ & 0.36 & $\mathrm{RTI}$ & 0.40 & RTI & 0.45 \\
\hline Fall & 0.19 & Suicide & 0.17 & Fall & 0.25 \\
\hline Suicide & 0.13 & Fall & 0.16 & Drowning & 0.16 \\
\hline Drowning & 0.10 & Drowning & 0.13 & Suicide & 0.15 \\
\hline Poisoning & 0.05 & Poisoning & 0.07 & Poisoning & 0.11 \\
\hline Fire & 0.02 & Fire & 0.01 & Fire & 0.01 \\
\hline
\end{tabular}

RTI: road traffic injury.

Source: China Death Surveillance Database, 2016 (http://en.nhc.gov.cn/).

The results of our research showed that the life expectancy of the Chinese population increased by 1.13 years and the rate of men ( 1.42 years) was faster than that of women ( 0.78 years) after the elimination of injury-related mortality. Our results are consistent with studies in other countries. Rockett 22 conducted a research on life expectancy in nine developed countries, whose criteria selection combined respective minimums of a population of 15 million, gross domestic product (GDP) per capita of USD 13,000 and population life expectancy of 75 years. His research showed that although women's life expectancy is generally higher, after the removal of injury-related deaths, the increase in men's life expectancy (0.88-2.08 years) is greater than that of women (0.45-1.09 years). Studies by Manuel 23 and Conti 24 had shown that men's life expectancy increases more than women after eliminating the effects of injury. The reason for this phenomenon may be that men face more dangers than women. Compared with female, men are more likely to engage in heavy and dangerous work, which means more opportunities for injuries 25 . The growth of life expectancy in rural (1.27 years) and the Western (1.37 years) residents is higher than that of urban ( 0.85 years), the Eastern (1.00 years) and Central (1.1 years) regions. This may be related to poor traffic conditions in rural and the Western regions, which are more likely to cause traffic accidents, as well as the worse level of medical care when compared to the urban, Eastern and Central regions 10. These results suggested that we should strengthen the prevention and control of injury among rural and Western residents, especially among men.

Compared with 2006, life expectancy loss caused by RTIs was higher in 2016. The result is consistent with other studies 24,26 . With the development of China's economy, the number of civil vehicles has increased rapidly, and events such as drunk driving, fatigue driving and traffic violation accidents occur frequently 27,28 . The death rate related to RTIs increases rapidly, leading to a huge impact on the life expectancy of residents 25 . In addition, our study also found that the loss of life years due to RTIs-related deaths decreased gradually with increasing age, showing that deaths caused by RTIs mainly affect young residents. Law enforcement officials should strengthen the traffic safety education of young drivers.

Another noteworthy finding of our study was that the falls had a conspicuous impact on the life expectancy for children under 5 years old and adults aged over 65 years. After removing RTIs, falls became the most important factor affecting children's life expectancy. According to the WHO, nearly 47,000 children under the age of 20 die every year due to falls 29 . In 1988, the US statistics showed that the falls were the second most common cause of injury among children under the age of 1730 . In China, an epidemiological survey of child injury conducted in the Jiangxi Province showed that falls ranked second in injury categories, accounting for $28.44 \%$, and was the first cause of child disability, accounting for $37.54 \% 31$. Ren Yuqian et al. 32 studied the children with accidental injuries admitted to the Shanghai Jiaotong University Affiliated Hospital from 2011 to 2014 and found that the RTIs were the main injury categories, followed by falls. Such events are largely related to the psychologicalphysiological behavioral characteristics of children. Smaller babies fall from beds, stairs, and slippery 
floors due to poor balance. A survey from the Beijing Children's Hospital reported that parents locked their children in the house alone, and thus children fell due to fear after climbing over a window or balcony 33 . Specific reasons for such falls may differ, so preventive measures should be targeted. For the age group of 65 years and above, falls are the first factor affecting the life expectancy, which may be related to the aging of the Chinese population. Currently, China is not only the country with the largest number of elderly people in the world, but also a developing country with a rapidly aging population. As body function declines with age, one's ability to respond to falls decrease. This is also a population with high incidence of osteoporosis, which is prone to fall-related death $15,34,35$. Therefore, the government should actively carry out programs for fall interventions for the older population in the community, strengthen the publicity and education and improve the infrastructure of communities and families to prevent falls.

In order to minimize the impact of injury on residents' life expectancy and promote health equity in all age groups, future interventions should focus on injury prevention efforts for male, rural and the Western residents. Apart from this, relevant departments should carry out targeted injury prevention interventions for different age groups. Interventions to reduce RTIs should be focused on the people under 65 years old; health education and surveillance on falls should focused on children under 5 years old; community and family falls prevention interventions should be conducted for the elderly aged 65 years and over. These prevention interventions are effective measures to increase life expectancy.

This research had several limitations. Because the cause-eliminated life table mainly reflects the impact of different causes of death on life expectancy, the results cannot be used to evaluate the impact of different causes on disability prevalence rate or quality of life. As a result, the findings of the study cannot fully reflect the impact of injury on health. In order to assess the impact of different causes on population health, future research should use more comprehensive indicators, such as years of disability (YLDs), disability-adjusted life years (DALY) and healthy life expectancy. In addition, since the relevant death data in our study come from the China Death Surveillance Database of 2016, it is impossible to accurately measure the actual underreporting of populations of different ages, genders and regions, which made the life expectancy calculated in our study higher than the estimate of the census data. Despite these limitations, the results of this study may be supplementary to other studies based on data from China Death Surveillance Database in the context of the incompleteness of the death registry system in China.

\section{Conclusions}

In conclusion, significant progress has been made in injury prevention in China during the decade 2006-2016, but the impact of injury on residents' life expectancy cannot be ignored. The impact of mortality caused by injury on residents of different genders and regions is also significantly different. By reducing the deaths caused by injury, the life expectancy level is likely to improve further. In addition, special attention should be given to the impact of RTIs on the life expectancy of residents and to the reduction of premature deaths caused by injury to children and the older population. 


\section{Contributors}

Li F. designed the study and revised the article. Wen S. contributed to interpretation of the results and revised the article. Tang Q. wrote the paper. Zhou Q. contributed to the data collection, data management, and statistical analysis and and revised the article. Hao Y. and revised the article. Sun C. conceived and designed the study and revised the article.

\section{Additional informations}

ORCID: Fangwei Li (0000-0001-8672-8569); Shujing Wen (0000-0002-9381-7268); Qixin Tang (0000-0002-2253-309X); Qianyu Zhou (00000002-9458-5008); Yibin Hao (0000-0003-26895941); Changqing Sun (0000-0001-5509-9237).

\section{Acknowledgments}

We thank all the research staff from Chinese Center for Disease Control and Prevention for their collection of data. We also thank all the participants for their participation and contribution. National Social Science Foundation of China for the financial support.

\section{References}

1. Li D. Present situation of policy measures for and forecasting of injury prevention and control in China. Chinese Journal of Health Education 2005 ; $21: 258-61$.

2. Xie T, Li D. Status of injury and disease burden. Journal of Environmental Hygiene 2004; 31:309-14.

3. Chandran A, Hyder AA, Peek-Asa C. The global burden of unintentional injuries and an agenda for progress. Epidemiol Rev 2010; 32:110-20.

4. Dong HL, Guo XL,Wang YY, Zhao FY. Life table analysis of the impact of injury on average life expectancy. Health Economic Research 2016; 2:30-3.

5. Wang SY. From data to action: challenge China's injury control work. Chinese Journal of Preventive Medicine 2006; 4:221-2.

6. Judge K. Income distribution and life expectancy a critical appraisal. BMJ 1992; 304:715-6.

7. Sede PI, Ohemeng W. Socio-economic determinants of life expectancy in Nigeria (19802011). Health Econ Rev 2015; 5:2.

8. Tian K. The average life expectancy change of Chinese population and its influence on life insurance. Chinese Insurance 2011; 7:24-7.

9. Brownlee J. Notes on the biology of a lifetable. Journal of the Royal Statistical Society 1919; 82:34-77.

10. Fei FR, Zhong JM, Yu M, Gong WW, Wang M, Pan J, et al. Impact of injury-related mortality on life expectancy in Zhejiang, China based on death and population surveillance data. BMC Public Health 2017; 18:24.

11. Li Q, Ma S, Bishai D, Hyder AA. Potential gains in life expectancy by improving road safety in China. Public Health 2017;144 Suppl:S57-61.

12. Li GQ, Fan J, Liu J, Wang W, Wang M, Qi Y, et al. Impact of cerebrovascular disease mortality on life expectancy in China. Biomed Environ Sci 2014; 27:169-75.

13. Zhao D, Liu J. The burden of cardiovascular disease and its impact on life expectancy in China. Eur Heart J 2014; 35:2625-6.

14. Li J, Luo C, Klerk N. Trends in infant/child mortality and life expectancy in Indigenous populations in Yunnan Province, China. Aust N Z J Public Health 2008; 32:216-23.

15. Peng K, Tian M, Andersen M, Zhang J, Liu Y, Wang $\mathrm{Q}$, et al. Incidence, risk factors and economic burden of fall-related injuries in older Chinese people: a systematic review. Inj Prev 2019; 25:4-12.

16. Meng L, Zeng W, Gan Z, Zhou H, Zhong P. Study on the strategy of rural industry development in the central China under the background of urban-rural integration. Asian Agricultural Research 2018; 10:6-8.

17. Xia W, Ren H, Ma E, Yang G. Mortality trends for ischemic heart disease in China: an analysis of 102 continuous disease surveillance points from 1991 to 2009. BMC Public Health 2018; 18:52. 
18. Yang G, Hu J, Rao KQ, Ma J, Rao C, Lopez AD. Mortality registration and surveillance in China: history, current situation and challenges. Population Health Metrics 2005; 3:3.

19. Liu S, Wu X, Lopez AD, Wang L, Cai Y, Page A, et al. An integrated national mortality surveillance system for death registration and mortality surveillance, China. Bull World Health Organ; 94:46-57.

20. Chiang CL. Introduction to stochastic processes in biostatistics. Hoboken: John Wiley \& Sons; 1968.

21. Fang JQ. Health statistics. People's Medical Publishing House 2012:369-76.

22. Rockett IRH. Injury elimination and survival. Public Health 1998; 112:27-30.

23. Manuel DG, Schultz SE, Kopec JA. Measuring the health burden of chronic disease and injury using health adjusted life expectancy and the Health Utilities Index. J Epidemiol Community Health 2002; 56:843-50.

24. Conti S, Farchi G, Masocco M, Toccaceli V, Vichi M. The impact of the major causes of death on life expectancy in Italy. Int J Epidemiol 1999; 28:905-10.

25. Hu Y, Wu L, Yu X, Zhang D, Liu X, Wang Y. Analysis of injury death trends among women in Macheng City, China, 1984-2008. BMC Public Health 2011; 11:698-704.

26. Wang Y, Ji CR, Zhou MG, Ji YB, Liu YN, Duan LL. The nationwide impact of injury-related deaths on average life expectancy in China. Biomed Environ Sci 2014; 27:304-10.

27. Cobiac LJ, Mizdrak A, Wilson N. Cost-effectiveness of raising alcohol excise taxes to reduce the injury burden of road traffic crashes. Inj Prev 2019; 25:58-62.
28. Knott M, Classen S, Krasniuk S, Tippett M, Alvarez L. Insufficient sleep and fitness to drive in shift workers: a systematic literature review protocol. Inj Prev 2019; 25:589-94.

29. World HealthOrganization. World report on child injury prevention. Geneva: World Health Organization; 2008.

30. Scheidt PC, Harel Y, Trumble AC, Jones DH, Overpeck MD, Bijur PE. The epidemiology of nonfatal injuries among US children and youth. Am J Public Health 1995; 85:932-8.

31. Team JCsIIP. Epidemiological Survey of Child Injury in Jiangxi Province. Chinese Journal of Preventive Medicine 2007; 8:521-6.

32. Yuqian CYR, Yucai Z, Liang X, Qunfang R, Guoliang T. Epidemiological of unintentional injuries in children: analysis of 192 cases treated in pediatric intensive care unit. Chinese Journal of Emergency Resuscitation and Disaster Medicine 2015; 10:104-7.

33. Chen YJ, Fan ZH,Wang YH. A hospital based survey on childhood injuries. Chinese Journal of Pediatrics 1999; 37:664-6.

34. Cheng P, Wang L, Ning P, Yin P, Schwebel DC, Liu J, et al. Unintentional falls mortality in China, 2006-2016. J Glob Health 2019; 9:010603.

35. Zhou BY, Yu DN, Tao YK, Shi J, Yu PL. Relationship between fall and frailty index in elderly adults of urban community in Beijing. Zhonghua Liu Xing Bing Xue Za Zhi 2018; 39:308-12. 


\section{Resumo}

O estudo teve como objetivos analisar o impacto dos óbitos por causas externas na expectativa de vida na China em 2016 e identificar a população de risco. Foram utilizadas tábuas de mortalidade padronizadas para calcular a expectativa de vida e a expectativa de vida depois de eliminar as causas externas, com base nos dados de mortalidade do Sistema Nacional de Vigilancia da Mortalidade. Em 2016, a expectativa de vida dos chineses era 78,91 anos. Depois de eliminar a mortalidade por causas externas, a expectativa de vida dos chineses aumentou em 1,13 anos, e o aumento foi maior nos homens e nos moradores da área rural, comparados às mulheres e aos moradores da área urbana. A expectativa de vida das regiões Leste e Central aumentou mais lentamente do que na região Oeste do país. Os acidentes de trânsito foram o fator de maior impacto sobre a expectativa de vida, seguidos de quedas. As quedas tiveram um impacto maior sobre a expectativa de vida nas crianças abaixo de 5 anos e nos idosos acima de 65 anos de idade. O estudo indica que os óbitos por causas externas tiveram um impacto relevante na expectativa de vida na China. As lesões por acidentes de trânsito merecem mais atenção, e medidas efetivas devem ser tomadas para reduzir os óbitos por causas externas para aumentar a expectativa de vida na população chinesa, principalmente nas crianças abaixo de 5 anos e nos idosos acima de 65 anos. A redução dos óbitos por causas externas deverá melhorar mais ainda o nível de expectativa de vida.

Ferimentos e Lesões; Causas Externas; Causas de Morte; Expectativa de Vida

\section{Resumen}

El objetivo de este estudio fue ilustrar el impacto de los fallecimientos relacionados con lesiones $y$ la esperanza de vida en China en 2016, así como identificar a la población de alto riesgo. Las tablas de estándar de vida se utilizaron para calcular la esperanza de vida y la causa de la supresión de esperanza de vida se calculó utilizando datos de mortalidad del sistema de vigilancia de la mortalidad. En 2016, la esperanza de vida de los chinos residentes era 78,91 años. Tras eliminar la mortalidad relacionada con lesiones, la esperanza de vida de los residentes se incrementó en 1,13 años, que fue mayor en hombres, residentes en áreas rurales, comparada con las mujeres, residentes en áreas urbanas. La esperanza de vida en las regiones orientales y centrales se incrementó lentamente, comparada con la región occidental. El factor de mayor influencia en la esperanza de vida fue las lesiones en accidentes de tráfico, seguidas de las caídas. Las caídas tuvieron un impacto mayor en la esperanza de vida para los niños menores de 5 años, así como los ancianos con una edad por encima de los 65 años. Este estudio indica que las muertes causadas por lesiones tuvieron un impacto notorio en la esperanza de vida en China. Se debe prestar más atención a las lesiones por accidente de tráfico, y se deberían tomar medidas preventivas efectivas para reducir las muertes relacionadas con las lesiones para incrementar la esperanza de vida de los residentes, especialmente en niños menores de 5 años y personas mayores con más de 65 años. Si se reducen las muertes causadas por lesiones, cabe esperar que mejore el nivel de esperanza de vida.

Heridas y Traumatismos; Causas Externas; Causas de Muerte; Esperanza de Vida
Submitted on 02/Jul/2019

Final version resubmitted on $03 / \mathrm{Jan} / 2020$

Approved on 17/Apr/2020 